\title{
TEKNOLOGI PENYAMAKAN KULIT KRAS BUAYA
}

Bambang Oetojo, Sri Mulati, Rifan Hadi, Kabul Sumarsono, Widari, Hasan Basalamah, Muchtar Lutfie

\section{ABSTRACT}

The objective of this research is to know the influence of basic chromium tanning agent used to the colour and softness of the crust leather. In the carrying out it was used 12 pieces green salted cured crocodile skin of 11 up to 14 inch widht. All of the crocodile skins were processed up to pikcling with the same way. The crocodile skins were than pre-tanned with basic chromium tanning agent varying from $0.5 \%$; $1.0 \%$ and $1.5 \%$. Each treatment needed two pieces of crocodile skin and was done twice. They were than tanned with $30 \%$ Irgatan LV. The Crust leather out put from the research was visual investigated for the Colour and the softnees. Statistical analysis paints out that there is extremely signify difference $(P<0.01)$ the influence of the use of basic chromium tanning agent to the coulor and the softnees of the crusts leather. Practical meaning of this research is that to tan crocodile skin to be crust leather it is used $1.0 \%$ basic chromium tanning agent $30 \%$ Irgatan LV.

\section{INTISARI}

Tujuan Penelitian ini adalah untuk mengetahui pengaruh bahan penyamak krom basa yang digunakan terhadap warna dan kelemasan kulit kras. Dalam pelaksanaannya digunakan 12 Lembar dengan lebar 11 sampai 14 inci yang diawet dengan garam. Semua kulit buaya diproses sampai dengan pengasaman dengan cara yang sama. Kemudian kulit buaya tersebut disamak pendahuluan dengan bahan penyamak krom basa yang bervariasi dari $0,5 \%$; $1.0 \%$ dan $1.5 \%$. Setiap perlakuan memerlukan dua lembar kulit buaya dan dikerjakan dua kali. Kemudian kulit buaya tersebut disamak dengan 30\% Irgatan LV. Kulit kras yang dihasilkan dari penelitian diamati warna dan kelemasannya. Analisa statistik menunjukkan bahwa ada beda nyata $(P \leq 0,01)$ pengaruh penggunaan bahan penyamak krom basa terhadap warna dan kelemasannya kulit kras. Arti Praktis penelitian ini adalah untuk menyamak kulit buaya menjadi kulit kras digunakan 1,0\% bahan penyamak krom basa dan $30 \%$ Irgatan LV.

\section{PENDAHULUAN}

Dalam beberapa hal teknologi penyamakan kulit reptil, dalam hal ini kulit buaya, dikerjakan dengan cara yang sama seperti pada kulit kerbau, kulit domba dan kulit kambing, (1.2). Seperti dalam proses untuk menghilangkan 
lu dan epidermis pada bewan lainnya, maka unuk menghilangkan sisik da kulit buaya digunakan pula bahan-bahan seperti $\mathrm{Na}_{2} \mathrm{~S}$ dan $\mathrm{Ca}(\mathrm{OH})_{2}$. Selain kulit yang berukuran besar, kulit buaya pada umumnya disamak demikian rupa sehingga kulit jadi (leather) yang dihasilkan berwarna natu. I. Sebab dengan demikian gambar pada bagian rajah dapat lebih jelas. Hal penting sekali untuk kulit buaya. (1)

Bahan penyamak yang dapat digunakan untuk menyamak kulit buaya alah sama seperti untuk menyamak kulit sapi, kulit kerbau, kulit domba n kulit kambing, yaitu bahan bahan penyamak mineral, bahan penyamak bati dan bahan penyamak sintetis. (4.5) Karena setiap bahan penyamak empunyai kelebihan dan kekurangan, maka apabila dalam proses penyaakan menggunakan dua atau lebih bahan penyamak, kekurangan-kekungan tersebut dapat dikurangi.(5)

engan demikian dapat meningkatkan mutu kulit jadi yang dihasilkan. nyamakaan kulit dengan menggunakan dua atau lebih bahan penyamak bati, dinamakan penyamakan kombinasi. (5.6.7)

Adapun yang dinamakan kulit Kras (crust) adalah kulit matang yang dimak dengan metoda penyamakan kombinasi, yang belum mengalami nyempurnaan dan mudah dibasahkan kembali. (8)

alam hal ini pada proses penyamakan dari kulit mentah menjadi kulit kras enggunakan bahan penyamak krom sulfat basa $1,5 \%$ dan bahan penyamak tesis. $15-20 \%$ Dengan menggunakan bahan penyamak sintesis dapat erubah krom sulfat basa menjadi gugusan yang warnanya lebih muda. slit jadi yang dihasilkan menjadi lebih berisi, padat, terang dan bersih.(9)

\section{ATERI DAN METODA}

ateri

Dalam penilitian ini menggunakan 12 lembar kulit buaya diawet garam ngan ukuran $11-14$ inchi untuk setiap lembar. Bahan pembantu penyaak yang dipergunakan dalam penelitian ini adalah $\mathrm{Na}_{2} \mathrm{~S}, \mathrm{Ca}(\mathrm{OH})_{2} \mathrm{SO} 4$, $\mathrm{COOH}, \mathrm{H}_{2} \mathrm{SO}_{4}, \mathrm{Na}_{2} \mathrm{SO}_{3}, \mathrm{Na} \mathrm{Cl}$, Antijamur, bahan pengikis protein (bag agent), bahan pengurang lemak (degreasing agent) dan minyak sulfat. han penyamak yang digunakan dalam penelitian ini adalah garam krom Ifat basa dan bahan penyamak sintesis.

lat-alat yang dipergunakan dalam penelitian ini adalah bak pengapuran, sau buang daging, sikat buang sisik, timbangan dan drum penyamakan.

\section{etoda}

Semua kulit diproses sampai dengan pengasaman sesuai dengan metoda ng ada di Balai Besar Penelitian dan Pengembangan Industri Barang Kulit, aret dan Plastik. Selanjutnya kulit disamak menjadi kulit krom basah (wet ue) dengan garam krom sulfat basa $\left(\mathrm{Cr}_{2} \mathrm{O}_{3}\right)$ yang bervariasi dari $0.5 \%$,
$1.0 \%$ dan $1.5 \%$. Untuk setiap perlakuan menggunakaan dua lembar kulit buaya dengan satu kali ulangan. Pada penyamakan ulang digunakan Irgatan LV sebesar $30 \%$.

Adapun langkah-langkah yang dikerjakan dalam penyamakan kulit buaya menjadi kulit krom basah adalah sebagi berikut :

\section{Pencucian (washing)}

Proses ini dimaksudkan untuk menghilangkan garam pengawet yang terdapat pada kulit. Pencucian ini dikerjakan di dalam drum. Air masuk melalui as drum yang berlubang dan keluar melalui tutup drum yang berlubanglubang pula. Pada waktu pencucian, drum (molen) diputar selama 60 menit atau sampai garam pengawet benar-benar hilang.

\section{Pengapuran (liming)}

Proses ini dimaksudkan untuk menghilangkan lapisan yang menutupi kulit bagian rajah serta untuk membengkakkan kulit.

Adapun pelaksanaannya adalah dengan memasukkan kulit kedalam suatu larutan $\mathrm{Na}_{2} \mathrm{~S}$ dengan kepekatan 10 Be selama \pm 24 jam. Selanjutnya lapisan yang menutupi kulit bagian rajah dihilangkan dengan sikat dan sisa-sisa daging dihilangkan dengan pisau.

\section{Pengapuran putih (Reliming)}

Proses ini dimaksudkan untuk menghilangkan zat-zat kulit yang tidak diperlukan serta untuk membengkakkan kulit.

Adapun pelaksanaannya adalah dengan memasukkan kulit kedalam suatu larutan yang terdiri atas air : $200 \%$ dan $\mathrm{Ca}(\mathrm{OH})_{2}: 2 \%$ Proses ini dikerjakan selama \pm 24 jam.

\section{Pembuangan kapur (Deliming)}

Proses ini dimaksudkan untuk menghilangkan kapur yang terdapat di dalam kulit.

Adapun pelaksanaannya adalah dengan memasukkan kulit ke dalam drum yang berisi larutan yang terdiri atas air : 200\% dan $\left(\mathrm{NH}_{4}\right)_{2} \mathrm{SO}_{4}: 1 \%$. Dan diputar selama 30 menit. Selanjutnya ditambahkan $\mathrm{H}_{2} \mathrm{SO}_{4}: 0.5 \%$ dan drum diputar selama 30 menit. Proses ini selesai apabila penampang kulit berwarna putih terhadap phenolptalein indikator.

\section{Pengikisan Protein (Bating).}

Pengikisan protein merupakan proses enzimatik dan dimaksudkan untuk menyempurnakan proses-proses sebelumnya dan agar kulit jadi (leather) yang dihasilkan tidak lenting.

Adapun pelakasanaanya adalah dengan menambahkan bahan pengikis protein bating agent sebesar $0.6 \%$ ke dalam larutan pada proses pembuangan kapur, selanjutnya drum diputar selama 60 menit. Proses ini selesai apabila 
kulit ditekan dengan ibu jari dan bekasnya tidak lekas timbul kembali.

\section{Pengurangan lemak (Degreasing)}

Proses ini dimasudkan untuk mengurangi kandungan lemak alam yang ada di dalam kulit. Karena lemak alam mengganggu dalam proses penyamakan dan pengecatan dasar.

Adapun pelaksanaannya adalah dengan menambah bahan pengurang lemak (degreasing agent) sebesar $0.5 \%$ ke dalam larutan pada proses pembuangan kapur dan pengikisan protein. Selanjutnya drum diputar selama 15 menit.

\section{Pengasaman (Pickling)}

Proses ini dimaksudkan untuk membuat kulit dalam keadaan asam, sehingga $\mathrm{pH}$ kulit sesuai dengan $\mathrm{pH}$ zat penyamak yang akan digunakan. Adapun pelaksanaanya adalah dengan memasukkan kulit ke dalam drum yang berisi suatu larutan yang terdiri atas air : $80 \%$ dan $\mathrm{NaCl}: 10 \%$, kemudian drum diputar selama 10 menit. Selanjutnya $\mathrm{HCOOH}$ pekat sebesar: $0.5 \%$ yang diencerkan terlebih dahulu dengan air ditambahkan melalui as yang berlubang seraya drum diputar terus. Setelah drum diputar selama 15 menit, kemudian $\mathrm{H}_{2} \mathrm{SO}_{4}$ pekat sebesar $1.5 \%$ yang diencerkan terlebih dahulu dengan air ditambahkan melalui as yang berlubang seraya drum diputar terus. Larutan $\mathrm{H}_{2} \mathrm{SO}_{4}$ dimasukkan ke dalam drum sebanyak tiga kali dengan selang waktu 15 menit. Setelah larutan $\mathrm{H}_{2} \mathrm{SO}_{4}$ dimasukkan semua, drum diputar selama 120 menit, atau apabila $\mathrm{pH}$ larutan pengasaman dan kulit mencapai 3.5 serta penampang kulit berwarna kuning terhadap Brome Creasol Green Indikator.

\section{Penyamakan pendahuluan (pre tanning)}

Maksud penyamakan pendahuluan adalah agar kulit keadaannya lebih stabil, sehingga zat-zat kulit yang mudah rusak menjadi tahan terhadap mikroorganisme dan membantu masuknya bahan penyamak sintetis ke dalam kulit.

Adapun pelaksanaannya adalah dengan menambahkan garam krom sulfat basa ke dalam larutan pengasam yang berisi kulit. Setiap perlakuan menggunakan dua lembar kulit dan bahan penyamak garam krom sulfat basa yang digunakan bervariasi dari $0.5 \%, 1.0 \%$ dan $1.5 \%$. Perlakuan dengan satu kali ulangan.

Drum diputar selama 120 menit, atau sampai bahan penyamak garam krom sulfat basa benar-benar masuk ke dalam penampang kulit. Selanjutnya basisitas dinaikkan dengan jalan menambahkan $\mathrm{Na}_{2} \mathrm{CO} 3$ sebesar $1 \%$ melalui as drum yang berlubang sebelum ditambahkan $\mathrm{Na}_{2} \mathrm{CO}_{3}$ dilarutkan terlebih dahulu dengan air sebesar 10 kali. berat $\mathrm{Na}_{2} \mathrm{CO}_{3}$. Larutan $\mathrm{Na}_{2} \mathrm{CO}_{3}$ dimasukkan ke dalam drum sebanyak tiga kali dengan selang waktu 15 menit seraya drum diputar terus. Setelah larutan $\mathrm{Na}_{2} \mathrm{CO}_{3}$ dimasukkan semua, drum diputar selama 120 menit atau sampai kulit masak. Uji kemasakan kulit dengan cara boiling test. Setelah kulit masak, ditambahkan anti jamur sebesar $0.5 \%$ dan drum diputar selama 15 menit.

\section{Penetralan (Neutralising)}

Proses ini dimaksudkan untuk membuat kulit dalam keadaan netral untuk menyesuaikan proses selanjutnya.

Adapun pelaksananannya adalah dengan memasukkan kulit ke dalam drum (molen) yang berisi air sebanyak $200 \%$. Seraya drum dipurtar $\mathrm{Na}_{2} \mathrm{CO}_{3}$ sebesar $1.5 \%$ yang telah dilarutkan terlebih dahulu dengan air, dimasukkan melalui as drum yang berlubang. Larutan $\mathrm{Na}_{2} \mathrm{CO}_{3}$ dimasukkan ke dalam drum sebanyak tiga kali dengan selang waktu 15 menit dan drum diputar terus. Proses penetralan selesai apabila penampang kulit berwarna biru terhadap Brome Creasol Green Indikator.

\section{Penyamakan (Tanning)}

Dalam proses penyamakkan dipergunakan Irgatan LV yang besarnya sama untuk setiap perlakuan. Adapun pelaksanaannya adalah dengan memasukkan kulit ke dalam drum (molen) yang berisi air sebanyak $200 \%$ dan Irgatan sebesar $30 \%$. Selanjutnya drum diputar selama 60 menit atau sampai larutan menjadi jernih.

\section{Peminyakan (Fatliquoring)}

Proses ini dimaksudkan untuk melicinkan serat-serat kulit, sehingga kulit kras yang dihasilkan keadaanya lemas.

Adapun pelaksanaannya adalah dengan memasukkan kulit ke dalam drum (molen) yang berisi air $60^{\circ} \mathrm{C}$ sebesar $300 \%$ dan minyak sulfat sebesar $4 \%$. Selanjutnya drum diputar selama 60 menit atau sampai minyak betul-betul masuk ke dalam kulit, yaitu apabila larutan menjadi jernih.

Untuk memecahkan emulsi minyak di dalam kulit, ke dalam drum ditambahkan $\mathrm{HCOOH}$ sebesar $0,5 \%$ dan diencerkan terlebih dahulu. Drum diputar selama 30 menit. Untuk mencegah tumbuhnya jamur pada kulit, ditambahkan cortymol $\mathrm{G}$ sebesar $0,5 \%$ dan drum diputar selama 30 menit.

\section{Pengeringan (Drying)}

Proses ini dimaksudkan untuk mengurangi kadar air di dalam kulit sebanyak mungkin.

Adapun pelaksanaannya adalah dengan jalan mengangin-anginkan kulit di tempat yang teduh.

\section{Pengujian organoleptis}

Kulit kras (crust) hasil penelitian diuji secara organoleptis mengenai warna dan kelemasannya.

\section{Analisa data}

Untuk mengetahui pengaruh bahan penyamak garam krom sulfat basa 
ada proses penyamakan kulit buaya menjadi kulit kras, digunakan analisa ecara statistik dengan analisa varians.

\section{Iasil Pembahasan}

Kulit Kras (crust) hasil penelitihan diuji secara organoleptis mengenai rarna dan kelemasannya.

\section{Varna}

Nilai uji warna kulit kras hasil penelitian dapat dilihat pada tabel 1. Seteah data pada tabel 1 dianalisa secara statistik dengan analisa varians pada abel 2 , menunjukkan ada beda sangat nyata $(P<0.01)$ pengaruh mengguakan bahan penyamak krom $\left(\mathrm{Cr}_{2} \mathrm{O}_{3}\right)$ terhadap warna kulit kras yang diasilkan.

Tabel 1. Nilai uji warna kulit kras buaya

\begin{tabular}{|c|c|c|c|c|c|c|}
\hline \multirow{2}{*}{$\mathrm{Cr}_{2} \mathrm{O}_{3} \%$} & \multirow{2}{*}{ Percobaan } & \multicolumn{5}{|c|}{ Nilai } \\
\hline & & 1 & 2 & 3 & 4 & 5 \\
\hline \multirow[t]{4}{*}{0.5} & I & 0.5 & 0.5 & 0.5 & 0.5 & 0.3 \\
\hline & & 0.4 & 0.5 & 0.3 & 0.7 & 0.3 \\
\hline & II & 0.5 & 0.5 & 0.5 & 0.5 & 0.5 \\
\hline & & 0.5 & 0.7 & 0.7 & 0.7 & 0.4 \\
\hline \multirow[t]{4}{*}{1.0} & I & 0.5 & 0.5 & 0.5 & 0.7 & 0.5 \\
\hline & & 0.3 & 0.7 & 0.7 & 0.7 & 0.3 \\
\hline & II & 0.4 & 0.5 & 0.7 & 0.5 & 0.3 \\
\hline & & 1.0 & 0.7 & 0.5 & 0.5 & 0.4 \\
\hline \multirow[t]{4}{*}{1.5} & I & 0.5 & 1.0 & 0.7 & 0,7 & 0.5 \\
\hline & & 0.5 & 0.5 & 0.5 & 0.5 & 0.5 \\
\hline & II & 1.0 & 0.7 & 0.5 & 0.5 & 0.4 \\
\hline & & 0.1 & 0.7 & 0.7 & 0.7 & 0.3 \\
\hline
\end{tabular}

Tabel 2. Analisa varians warna kulit kras buaya

\begin{tabular}{ccccc} 
S.O.V & df & SS & MS & F \\
\hline Perlakuan & 2 & 2.98 & 1.49 & $7.60 \mathrm{NS}^{* *}$ \\
Error & 57 & 11.2 & 0.196 & \\
\hline
\end{tabular}

ada beda sangat nyata.
Kelemasan

Nilai uji kelemasan kulit kras hasil penelitian dapat dilihat pada tabel 3 Setelah data pada tabel 3 dianalisa secara statistik dengan analisa varians pada tabel 4 , menunjukkan terdapat perbedaan yang sangat nyata $(\mathrm{P}<0.01)$ pengaruh variasi penggunaan penggunaan bahan penyamak krom $\left(\mathrm{Cr}_{2} \mathrm{O}_{3}\right)$ terhadap kelemasan kulit kras yang dihasilkan.

Tabel 3. Nilai uji kelemasan kulit kras buaya

\begin{tabular}{|c|c|c|c|c|c|c|}
\hline \multirow{2}{*}{$\mathrm{Cr}_{2} \mathrm{O}_{3} \%$} & \multirow{2}{*}{ Percobaan } & \multicolumn{5}{|c|}{ Nilai } \\
\hline & & 1 & 2 & 3 & 4 & 5 \\
\hline \multirow[t]{4}{*}{0.5} & I & 8 & 8 & 8 & 8 & 8 \\
\hline & & 8 & 8 & 8 & 8 & 8 \\
\hline & II & 8 & 7 & 7 & 8 & 7 \\
\hline & & 8 & 8 & 7 & 8 & 7 \\
\hline \multirow[t]{4}{*}{1.0} & I & 8 & 8 & 8 & 8 & 8 \\
\hline & & 8 & 8 & 8 & 8 & 7 \\
\hline & II & 7 & 7 & 8 & 9 & 8 \\
\hline & & 8 & 7 & 8 & 8 & 8 \\
\hline \multirow[t]{4}{*}{1.5} & I & 8 & 8 & 8 & 8 & 8 \\
\hline & & 8 & 7 & 7 & 8 & 7 \\
\hline & II & 8 & 8 & 8 & 9 & 7 \\
\hline & & 8 & 7 & 8 & 8 & 7 \\
\hline
\end{tabular}

Tabel 4. Analisa varians kelemasan kulit kras buaya

\begin{tabular}{ccccc}
\hline S.O.V & df & SS & MS & F \\
\hline Perlakuan & 2 & 2.98 & 1.49 & 7.60 NS** $^{* *}$ \\
Error & 57 & 11.2 & 0.196 & \\
\hline
\end{tabular}

** ada beda sangat nyata

\section{KESIMPULAN}

Ada beda sangat nyata $(\mathrm{P}<0.01)$ pengaruh variasi penggunaan bahan penyamak krom $\left(\mathrm{Cr}_{2} \mathrm{O}_{3}\right)$ terhadap warna dan kelemasan kulit kras buaya. Untuk menyamak kulit kras buaya menggunakan bahan penyamak krom $\left(\mathrm{Cr}_{2} \mathrm{O}_{3}\right)$ sebesar $1.0 \%$ dan Irgatan LV sebesar $30 \%$, hasilnya cerah dan lemas.

VOI VIII No 14 Tahun 1992/1993 
UCAPAN TERIMA KASIH.

Dengan selesainya penelitian dan tersusunya tulisan ini kami mengucapkan banyak terimakasih kepada Departemen Penelitian dan Pengembangan Industri Barang Bapak Kepala Balai Besar Penelitan staf yang telah memberikan pengarahKulit, Karet dan Plastik serta seman lainnya sehingga segala sesuatunya terlakan, bimbingan, biaya dan bantuan lainnya sehingg sega sana dengan baik.

DAFTAR PUSTAKA

1. Balai Penyelidikan Kulit : Penuntun Tentang Penyamakan Kulit

$$
\text { Yogyakarta (1959) }
$$
Yogyakarta (1959)
2. O'Flaherty, F.,W.T. Roddy and R.M. Lollar : The Chemistry and Tecnology
of Leather. Robert E. Krieger Publishing Company, Huntington, New York (1978) New York (1978)
3. Lever, J . : Crocodile Industry Training Manual. Wildlife Manual No. 75/1
March 1975, Wildlife Branch, B. A. S. F., Konedobu, Papau New Guinea (1979).

4. Balai Penelitian Kulit : Proses Penyamakan Kulit. Yogyakarta (1972)

5. Gustavson, K.H. : The Chesmistry of Tanning Processes. Akademic Press.

Inc. Publishers, New York, N. Y. (1958). st. Thomas Street, London Sei (1971)

7. Thorstensen, T.C: Practical Leather Technology. Robert E. Krieger

Publishing Company, Huntington, New York. (1976)

8. Departemen Perindustrian RI : Mutu dan Cara Uji Kulit Kras Sapi samak Krom Nabati. SII. 0641 - 82. Jakarta.

9. Ciba Geigy : Products for the Leather Industries. Zwitserlanland 30. 4. 74. 